mice and myself have had the privilege of breathing it". He suggested the use of oxygen in cases of pneumonia, and in the production of high temperatures.

Priestley believed in rapid publication, as did Faraday: "a person who means to serve the cause of science effectually, must hazard his own reputation so far as to risk mistakes in things of less moment", and all his results were available without delay to others, who could make better use of them than he could himself.

In August 1771 Priestley had found that vegetation, such as growing mint, spinach and groundsel, restores air vitiated by burning candles or by the breathing of animals: "the injury which is continually done to the atmosphere by the respiration of such a large number of animals . . . is, in part at least, repaired by the vegetable creation". In 1778 he found that water plants growing in water containing fixed air evolve oxygen. The part played by light in the process of photosynthesis, although known to Priestley, was more fully worked out by Ingen-Houss in 1779 .

Another "random experiment", made in 1781, in which moisture was found to result from the explosion of a mixture of common air and inflammable air, led to Cavendish's research on the formation of water from hydrogen and oxygen. In Priestley's own extension of this work, considerable confusion and error resulted from his neglect to distinguish clearly between hydrogen and other combustible gases, such as carbon monoxide and hydrocarbons. This confusion remained until about 1800, when Cruickshank, of Woolwich, cleared up the matter.

Neither Priestley nor Cavendish was able to draw correct conclusions from his experiments. This was reserved for Lavoisier, "a great architect, who laboured little in the quarry" in the obscurity of which the two experimenters worked. Priestley never professed to be a chemist, and in the full sense of the word never was. His range of knowledge was too restricted, and he was thus incapable of appreciating the correct interpretations of his experiments when they were clearly placed before him.

Priestley's mind was powerful and broad: he was a good classical, oriental and modern linguist, who was able to argue points of theology with more orthodox divines with the scriptures in the original languages. He also had read extensively in philosophy and theology, and became involved in politics. His days became more and more occupied with these pursuits and he was the object of a growing animosity which finally hounded him from England to America, where he died. Although his experimental work imposed itself with unescapeable mastery on contemporary science, his theoretical contributions were negligible. Careful scientific thought does not flourish in such an environment.

No adequate account of Priestley's work in physics seems to be available. He published in 1767 a "History of Electricity", a subject which he calls his "favourite amusement". The experiments in electricity were begun at Nantwich and the book written in Warrington, with the encouragement of Benjamin Franklin. It contains an excellent account of early work in electricity and some new experiments, as well as the argument that electric forces obey an inverse square law because of the absence of charge inside a hollow conductor. In two papers published in 1769, "On the Lateral Force of Electric Explosions", he showed that a discharge from a Leyden jar when sent through a circuit composed of a metal chain with the ends brought together so as to form a small air gap, would in part jump the air gap of high resistance rather than pass through the metallic loop. In 1772 appeared two volumes on "The History and Present State of Discoveries Relating to Vision, Light and Colours", which were not so well received as the history of electricity.

"Human happiness", Priestley tells us in a characteristically discursive preface to the "History of Electricity", "depends chiefly upon having some object to pursue, and upon the vigour with which our faculties are exerted in the pursuit". He was happy in having several objects for the exercise of his vigorous and original mind. In science he was a great explorer, opening out in his rapid and fortunate survey a great number of sites, the rich treasures of which he left to others, equipped with greater patience and knowledge, to remove, arrange, classify and interpret. Such a pioneer fills a place in the annals of human achievement, and such a one was Joseph Priestley, the bicentenary of whose birth we now gratefully remember.

\title{
Priestley's Associations with London
}

\section{By H. G. WAYLING}

JOSEPH PRIESTLEY knew London well. Although he officiated for several years as a Dissenting minister at Nantwich and at Leeds, before coming to reside in London as Lord Shelburne's librarian, yet he generally managed to spend a month every year in the metropolis. His friendship with men like Benjamin Franklin, Dr. Richard Price, John Canton and Andrew Kippis encouraged him, while still a provincial pastor, to study natural philosophy earnestly. He speaks of the happy hours spent in their company at the London Coffee House on Ludgate Hill, the back premises of which abutted on to the Old Sessions House in Newgate. Over their cups, these philosophical enthusiasts discussed topical questions and laid plans for prospective publications.

A few yards higher up Ludgate Hill in St. Paul's churchyard, lived Joseph Johnson, the bookseller 
who acted as Priestley's literary and commercial agent. Priestley's correspondence was often directed to Johnson, at whose house the itinerant cleric also occasionally lodged. Another business acquaintance on whom he called was Edward Nairne, a mathematical instrument maker to the Royal Exchange, who lived at 20 Cornhill. Nairne supplied electrical machines and air-pumps to Priestley, who, in one of his letters, directs attention to the fact that the recently imported commodity, caoutchouc, could be purchased at this establishment.

Priestley must have been very familiar with the road from the Royal Exchange to Westminster. At 36 Craven Street, Strand, where Benjamin Franklin lodged-a tablet on the house commemorates the fact-Priestley was a frequent caller, sometimes dining with the distinguished American, who, like himself, was a member of the congregation assembling at the Essex House Chapel, Essex Street, just opposite the Courts of Justice. Sometimes he preached at this church, giving a rest to his great personal friend, the Rev. Theophilus Lindsey, the officiating minister. A little to the east of the Law Courts is Chancery Lane, connecting the Strand with Holborn, and in this latter thoroughfare, at Featherstone Buildings, Priestley, as Lindsey's guest, was always persona grata. These buildings, which are to the west of Chancery Lane and on the north side of Holborn, are famous also as the temporary home of Sir Walter Besant, when he was a student at King's College, and at the corner house Sheridan and Miss Linley first set up housekeeping after their elopement from Bath. Another of Priestley's clerical friends was Dr. Andrew Kippis, the biographer of John Canton, the Spitalfields schoolmaster, and likewise of Sir John Pringle, P.R.S.

As a preacher with a slight stammer, Priestley would not be at his best as a rhetorician, but in the library or round the festive board, what eruditional entertainments he must have given.
Can there be any doubt of the many cordial invitations he received when he came to London on his annual trip? Sometimes he stayed with Kippis in Whitcomb Street, parallel to the Haymarket, at other times with Dr. Price, who resided at Newington Green. It was this latter Nonconformist, who delivered a discourse on civil liberty at his chapel in the Old Jewry, Cheapside, which roused the ire of Edmund Burke to white heat. In the same place of worship, Priestley performed the mournful duty of preaching his friend's funeral sermon.

Having given some space to Priestley's devotional labours, it remains to mention those dealing with his scientific occupations. In 1773, he came to London as librarian and companion to Lord Shelburne, whose town residence, Lansdowne House, Berkeley Square, has recently been demolished. This post was ideally congenial to a man of Priestley's temperament and ability. The duties of his office were slight. In apartments reserved exclusively for him, he worked without let or hindrance. Distinguished foreigners paid visits to his laboratory and now and then William Pitt called on him to keep in touch with his latest experiments. At Lansdowne House on August 1, 1774, Priestley discovered oxygen, an event that will always be associated with his name.

After he left the service of Lord Shelburne, Priestley settled in Birmingham until a riotous rabble fired his house and chapel and caused him once again to seek safety among metropolitan sympathisers. Shortly after his flight to London, he was appointed to succeed Richard Price at the Gravel-pit Meeting House near Mare Street, Hackney. At this place of worship, he delivered his farewell sermon before sailing for America. His very last Sunday, however, was spent at the chapel in Essex Street, his friends "Sorrowing most of all at the words which he spake, that they would see his face no more". Next day he departed by river for Gravesend.

\section{The Recent Japanese Earthquake \\ By Dr. C. Davison}

\begin{abstract}
$\mathrm{NE}$ of the greatest earthquakes of the present century - a century that includes the Kansu earthquake of 1920 and the $K$ wanto earthquake of 1923-occurred off the east coast of Japan at about 5.31 p.m. on March 2, G.M.T. (or March 3, 2.31 a.m., Japanese time). The centre, as determined from the Kew record, lay in about lat. $40^{\circ} \mathrm{N}$., long. $144 \frac{1}{2}^{\circ} \mathrm{E}$. This point is 140 miles from the north-east coast of Japan, near the foot of the western slope of the Tuscaroora Deep, the depth of water in this region being 4,000 fathoms or about $4 \frac{1}{2}$ miles. It is, as Prof. Milne pointed out many years ago, the seat of some of the most violent of all Japanese earthquakes. Among them may be included those of the years 1563, 1659 and 1896 , and perhaps that of 1668 .
\end{abstract}

This centre is so distant from land that the destructive effects of the actual shock are not as a rule important. The recent earthquake was, however, of such strength that pictures were dislodged and ornaments thrown down within a district 235 miles in length from Morioka to Maebashi. It was strongest along the 54 miles of coast between Fudai and Kamaishi. As usual in great earthquakes, the shock was of considerable duration. At the observatory of Aomori, it was sensible for eight minutes, the greatest horizontal movement registered there being $87 \mathrm{~mm}$. or about $3 \frac{1}{2}$ in. At Tokyo, where it did not even shake down plaster or stop clocks, it was felt for four minutes.

Though much damage was caused by the 